\title{
Temporal expression of three conserved putative microRNAs in response of Citrus $\times$ Limon to Xanthomonas citri subsp. citri and Xanthomonas fuscans subsp. Aurantifolii
}

\author{
Milad AlizadeH $^{1}$, Hossein ASKari ${ }^{1 *}$, Massod Soltani NAJAFABadi ${ }^{2}$ \\ ${ }^{1}$ Shahid Beheshti University, Tehran, Iran \\ ${ }^{2}$ Oil Seeds Research Department, Seed and Plant Improvement Institute, Karaj, Iran
}

\begin{abstract}
Citrus canker is a widespread bacterial disease that severely affects citrus production. Xanthomonas spp. are the causative agents of the disease, which manifests as necrotic pustule-like lesions on the plant organs including leaves, fruits, and stems. MicroRNAs (miRNAs) are well-established post-transcriptional gene expression regulators that modulate plant responses during many stress conditions. Accordingly, some bacteria-responsive miRNAs have been shown to have regulatory functions in the plant-pathogen interactions. In this study, we successfully assessed the expression patterns of three conserved miRNAs: miR159, miR167, and miR398, in citrus $\times$ limon (lemon) infiltrated with Xanthomonas strains A and C using stem-loop RT-qPCR. Our results showed that the expressions of miR159 and mir167 have nearly similar patterns upon inoculations, while the expression of miR398 remains constantly up-regulated after an early induction.
\end{abstract}

Key words: lemon, citrus canker, conserved miRNAs, stem-loop RT-PCR, temporal expression

\section{Introduction}

The citrus genus, consisting of diverse fruit crops, makes a significant contribution to the human diet (Rouseff and Nagy, 1994; Economos and Clay, 1999). Among the commercial citrus fruits, lemon (citrus $\times$ limon) is considered an important horticultural product worldwide (USDA, 2013). Unfortunately, the lemon yield and fruit quality are frequently influenced by a wide range of biotic stresses. Xanthomonas citri subsp citri strain A (Xc), with a broad range of hosts, causes citrus canker disease, which is the most destructive threat to lemon production (Brunings and Gabriel, 2003). Citrus canker disease is characterized by symptoms such as water-soaked eruptions, circular lesions, and pustule-like lesions that appear on all plant tissues (Brunings and Gabriel, 2003). The lesions seem to be formed by changes in cell enlargement (hypertrophy) and cell division (hyperplasia) (Schubert et al., 2001; Brunings and Gabriel, 2003; Lin et al., 2009). In addition to the lesions, Xanthomonas fuscans subsp. aurantifolii strain $\mathrm{C}(\mathrm{XaC})$ can induce a hypersensitive response (HR) in lemon tissues (Brunings and Gabriel, 2003). HR is a form of cell death induced by the plant defense system to limit the growth and spread of pathogens at the infection site (Morel and Dangl, 1997).

In 2006, Jones and Dangl presented a simple model for the plant immune system, called the "zigzag" model (Jones and Dangl, 2006). In the first phase, conserved molecules shared by many classes of microbes (pathogen-associated molecular patterns) are recognized by pattern recognition receptors and trigger pattern-triggered immunity (PTI). Only successful pathogens can overcome PTI by the secretion of virulence effectors that lead to effector-triggered immunity (ETI). In both PTI and ETI, the perception of pathogens by a host triggers a series of immune responses including reactive oxygen species (ROS) signaling, hormone activation, and gene expression reprogramming (Nicaise et al., 2009).

*Corresponding author: Shahid Beheshti University, Tehran, Iran; e-mail: H_askari@sbu.ac.ir 
Moreover, ETI is associated with the appearance of HR (Heidrich et al., 2012).

MicroRNAs (miRNAs), 20-24 nucleotides in length, are post-transcriptional regulators of gene expression that play crucial roles during developmental processes and responses to various biotic and abiotic stresses (Khraiwesh et al., 2012; Barciszewska-Pacak et al., 2015). Furthermore, miRNAs have been demonstrated to be critical regulators in gene expression reprogramming during both PTI and ETI establishment (Navarro et al., 2006; Li et al., 2010). Moreover, several bacteria-responsive miRNAs play regulatory roles in hormone signaling pathways and gene regulatory systems (Zhang et al., 2011). In recent years, almost all plant hormones have been recognized as key regulators of plant immunity (Denancé et al., 2013). Among many characterized miRNAs, miR159 and miR167 are known to be involved in various hormone signaling pathways through the down-regulation of the expression of the MYB and ARF transcription factors, respectively ( $\mathrm{Li}$ et al., 2010; Zhang et al., 2011). The miR159 family members are specific to 3 GAMYB-like genes, MYB33, MYB65, and MYB101 (Alonso-Peral et al., 2010). MiR167 negatively regulates the auxin signaling pathway by targeting auxin response factor 6 and 8 (ARF6 and ARF8) transcripts (Glazińska et al., 2014). MiR398 targets copper- and zinc-containing superoxide dismutase (SOD) transcripts (Sunkar et al., 2006). SOD enzymes predominantly act to decrease high levels of ROS that are triggered during a pathogen attack (Jagadeeswaran et al., 2009).

The isolation of mature miRNAs and an accurate determination of their expression levels may be technically challenging (Benes and Castoldi, 2010). The stem-loop quantitative reverse transcription polymerase chain reaction (qRT-PCR) method, which takes advantage of specific stem-loop primers during cDNA synthesis, serves as a sensitive and specific strategy to quantify the abundance of mature miRNAs (Varkonyi-Gasic et al., 2007).

In the present study, the stem-loop RT-PCR method was used for analyzing the temporal expression of the selected miRNAs (miR398, miR159, and miR167) upon $\mathrm{Xc}$ and $\mathrm{XaC}$ infections.

\section{Materials and methods}

\section{Bacterial inoculum preparation}

Xanthomonas fuscans subsp. aurantifolii strain 9181 and Xanthomonas citri subsp. citri strain 9322 were ob- tained from the National Institute of Genetic Engineering and Biotechnology (NIGEB, Iran). Inoculum was prepared from three-day-old colonies grown on YPGA agar plates (yeast extract $3 \mathrm{gl}^{-1}$, peptone $5 \mathrm{gl}^{-1}$, glucose $10 \mathrm{gl}^{-1}$, and agar $20 \mathrm{gl}^{-1} ; \mathrm{pH}$ 6.5-7.0). Single colonies were transferred to $30 \mathrm{ml}$ of a yeast extract peptone (YP) broth medium ( $3 \mathrm{gl}^{-1}$ yeast extract and $5 \mathrm{gl}^{-1}$ peptone; $\mathrm{pH}=7.0$ ), and bacterial growth was monitored spectrophotometrically $\left(\mathrm{OD}_{600}\right)$ at 1 -h intervals for a 48 -h period. To prepare the bacterial inoculum, suspensions of bacterial cells were grown for $15 \mathrm{~h}$ in a rotary shaker $(180 \mathrm{rpm})$ at $28^{\circ} \mathrm{C}$. When $\mathrm{OD}_{600}$ reached 0.3 , bacterial suspensions were diluted to $\mathrm{OD}_{600}$ of 0.1 (corresponding to approximately $10^{7} \mathrm{cfu} / \mathrm{ml}$ ) by using a $0.075 \mathrm{M}$ phosphate buffer $\left(2.37 \mathrm{~g} \mathrm{NaH}_{2} \mathrm{PO}_{4}\right.$ and $\left.9.54 \mathrm{~g} \mathrm{Na}_{2} \mathrm{HPO}_{4}\right)(\mathrm{pH}$ $=7.0$ ).

\section{Plant material preparation and RNA extraction}

Experiments were conducted on two-year-old lemon plants (citrus $\times$ limon) obtained from certified nurseries from the south of Iran and grown in a greenhouse at $30 / 28^{\circ} \mathrm{C}$ (day/night) under $16 / 8$-h day/night conditions. To obtain new young leaves, plants were pruned a month before inoculation. Inoculation was performed using the handheld syringe method (Viloria et al., 2004). Leaves with $75 \%$ of the full expansion were used for inoculation by pressing the syringe tip against their abaxial surfaces. Inoculated regions of leaves were picked using a $0.5 \mathrm{~mm}$ cork borer and immediately snap-frozen in liquid nitrogen. Tissue sampling was done at $0.5,3,6,12,24,48$, and $72 \mathrm{~h}$ post-inoculation (hpi). Three biological replicates were considered for each treatment along with a control. The same number of leaves from the bottom, middle, and top of the plants were inoculated, and all the infected regions were pooled. Total RNA was extracted from the leaf tissues by using a TRIzol ${ }^{\circledR}$ reagent (Invitrogen, USA) and following the manufacturer's instructions. In brief, the frozen tissue was homogenized by Trizol, and the total RNA was precipitated with isopropanol and washed with $75 \%$ ethanol. Then, an RNA pellet was suspended with RNase-free water. Subsequently, RNA samples were treated by RNase-free DNaseI (Fermentas Life Sciences, Germany) according to the manufacturer's instructions. The integrity and quantification of the total RNA were evaluated by electrophoresis in a $2 \%$ agarose gel and using a NanoDrop 2000 UV-Vis spectrophotometer (Thermo Scientific, USA). 
Table 1. Primer sequences used for stem-loop RT-PCR and real-time PCR analysis. RTindicates stem-loop RT primer, $F$ indicates a specific forward primer, and $R$ indicates a universal RT primer

\begin{tabular}{|c|c|c|c|}
\hline $\begin{array}{l}\text { Primer } \\
\text { name }\end{array}$ & Primer sequences $\left(5^{\prime} \rightarrow 3^{\prime}\right)$ & $\mathrm{T}_{\mathrm{m}}$ & $\begin{array}{l}\text { Product } \\
\text { size }\end{array}$ \\
\hline $\operatorname{miR} 159$ & $\begin{array}{l}\text { GTC GTA TCC AGT GCA GGG TCC GAG GTA TTC GCA CTG GAT ACG ACT AGA GC (RT) } \\
\text { GCA GCG TTT GGA TTG AAG GGA (F) }\end{array}$ & 59.1 & 60 \\
\hline miR167 & $\begin{array}{l}\text { GTC GTA TCC AGT GCA GGG TCC GAG GTA TTC GCA CTG GAT ACG ACA AGA TC (RT) } \\
\text { CAC GGT GAA GCT GCC AGC AT }(\mathbf{F})\end{array}$ & 59.7 & 61 \\
\hline $\operatorname{miR} 398$ & $\begin{array}{l}\text { GTC GTA TCC AGT GCA GGG TCC GAG GTA TTC GCA CTG GAT ACG ACA AGG GG (RT) } \\
\text { GCA GCG TGT GTT CTC AGG TC (F) }\end{array}$ & 58.8 & 58 \\
\hline F-Box & $\begin{array}{l}\text { TTGGAAACTCTTTCGCCACT }(\mathbf{F}) \\
\text { CAGCAACAAAATACCCGTCT }(\mathbf{R})\end{array}$ & $\begin{array}{l}58.2 \\
58.8\end{array}$ & 121 \\
\hline $\begin{array}{l}\text { Universal } \\
\text { reverse } \\
\text { primer }\end{array}$ & GTG CAG GGT CCG AGG TAT TC & 58.1 & \\
\hline
\end{tabular}

\section{Primer design and stem-loop RT-PCR}

Primers were designed using mature miRNA sequences of citrus species (miR159, miR167, and miR398) retrieved from the Sanger Institute miRBase Sequence Database (Release 21, June 2014). The stem-loop reverse transcription primers and PCR primers were designed according to the criteria described in the stemloop RT-PCR method (Chen et al., 2005; Varkonyi-Gasic et al., 2007). The $3^{\prime}$ primer was a universal reverse transcription (RT) primer (Kramer, 2011; Varkonyi-Gasic et al., 2007). In our experiment, cDNA synthesis was conducted using an F-box reverse specific primer as a reference gene (Mafra et al., 2012) in a mixture with other stem-loop primers.

The specific forward primers and a universal reverse primer were tested with Primer Express 3.0 (Applied Biosystems, Foster City, CA, USA) (Table 1). The stemloop RT reactions were subjected to first-strand cDNA synthesis using the above-described primers and $400 \mathrm{ng}$ of DNaseI-treated total RNA by M-MLV reverse transcriptase (Vivantis, Vivantis Technologies, Subang Jaya, Malaysia) according to the manufacturer's instructions. Each sample, containing $400 \mathrm{ng}$ of RNA and a primer, in a volume of $12.5 \mu \mathrm{l}$ was heated at $85^{\circ} \mathrm{C}$ for $5 \mathrm{~min}$ to denature RNA and placed on ice for $5 \mathrm{~min}$ to stabilize the denatured structures. The RT reaction mixture consisted of dNTPs $(1 \mathrm{mM})$, RNase inhibitor $(1 \mathrm{U} / \mu \mathrm{l})$, and M-MLV reverse transcriptase $(20 \mathrm{U} / \mu \mathrm{l})$ in a final volume of $20 \mu$. The mixture was incubated for $30 \mathrm{~min}$ at $16^{\circ} \mathrm{C}$, $30 \mathrm{~min}$ at $42^{\circ} \mathrm{C}$, and $5 \mathrm{~min}$ at $85^{\circ} \mathrm{C}$, and held at $4^{\circ} \mathrm{C}$.
PCR amplification was performed on cDNA with a profile of $2 \mathrm{~min}$ at $94^{\circ} \mathrm{C}$, followed by 35 cycles of $94^{\circ} \mathrm{C}$ for $15 \mathrm{~s}, 60^{\circ} \mathrm{C}$ for $30 \mathrm{~s}$, and $72^{\circ} \mathrm{C}$ for $15 \mathrm{~s}$, and a final extension at $72^{\circ} \mathrm{C}$ for $3 \mathrm{~min}$. PCR products were analyzed on a $4 \%$ agarose gel.

\section{Real-time PCR analysis}

Real-time PCR reactions were performed on an Applied Biosystems 7500 instrument (Applied Biosystems). PCR mixture reactions consisted of SYBR green PCR master mix (AccuPower ${ }^{\circledR} 2 \mathrm{X}$ Greenstar qPCR Master Mix, Bioneer, Korea), $1 \mu \mathrm{l}$ of the diluted (1:20) cDNA template (from the previous step), Rox reference dye (1X), and primers $(0.5 \mu \mathrm{M})$ in a final volume of $10 \mu \mathrm{l}$. The real-time PCR amplification was carried out under the following conditions: pre-denaturation at $95^{\circ} \mathrm{C}$ for $10 \mathrm{~min}$, followed by 40 cycles of denaturing at $95^{\circ} \mathrm{C}$ for $15 \mathrm{~s}$, annealing, and extension at $60^{\circ} \mathrm{C}$ for $45 \mathrm{~s}$. An additional cycle was carried out to obtain the melting curve in the temperature range of $65-95^{\circ} \mathrm{C}$. Further, the PCR efficiency was estimated using the LinReg PCR software version 11.0 (Ruijter et al., 2009). The experiment was repeated thrice, and the reaction mixture with no template was included as a negative control to detect possible contaminations. The relative expression of miRNAs, normalized on the basis of the reference gene expression, was calculated using the $2^{-\Delta \Delta \mathrm{CT}}$ comparative method (Livak and Schmittgen, 2001). $2^{-\Delta \Delta \mathrm{CT}}$ is considered a fold change (FC), and data are presented as $\log _{2} \mathrm{FC}$. 

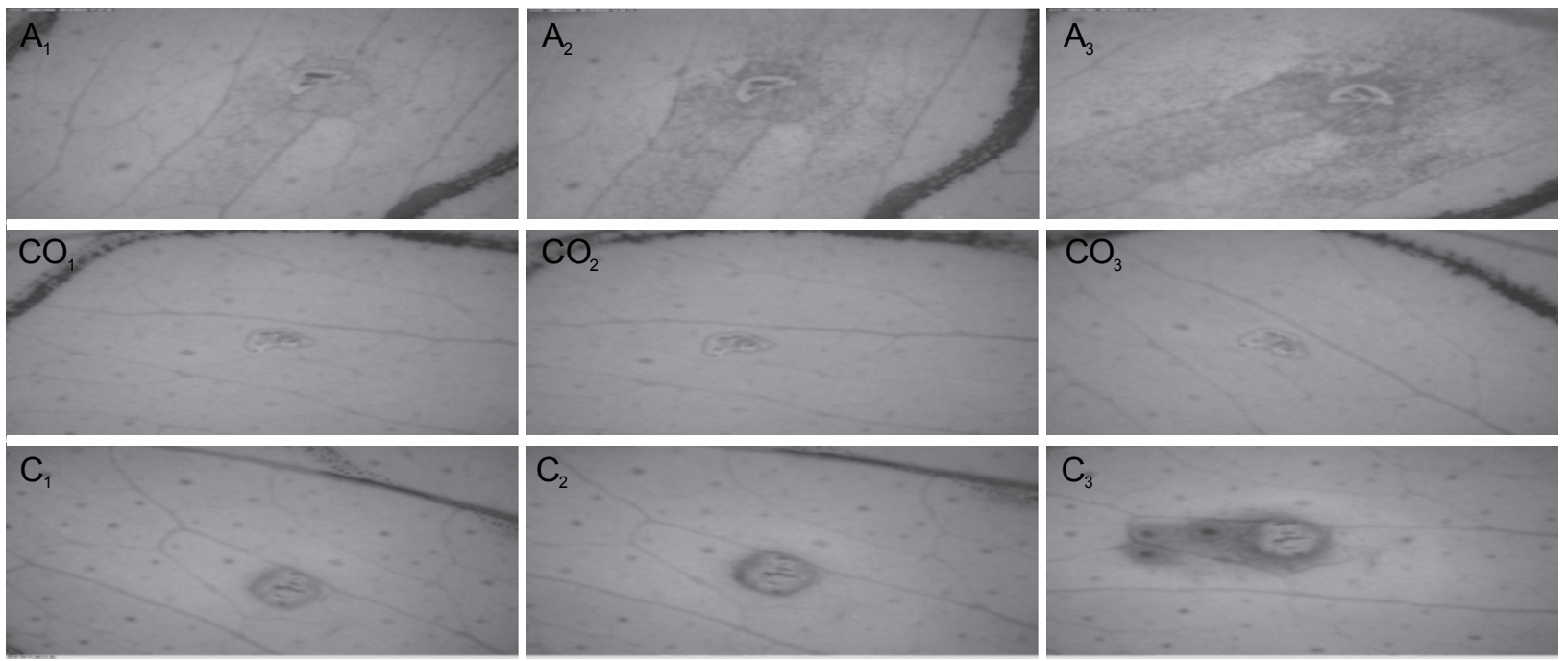

Fig. 1. Differential response of lemon leaves to Xanthomonas strains. Progression of disease symptoms during infection with $\mathrm{Xc}\left(\mathrm{A}_{1}-\mathrm{A}_{3}\right)$ as compared to the reaction when infected with $\mathrm{XaC}\left(\mathrm{C}_{1}-\mathrm{C}_{3}\right)$. As is shown in Figures $1 \mathrm{C}_{1}, 1 \mathrm{C}_{2}$, and $1 \mathrm{C}_{3}$, progression of the bacterial infection in an incompatible reaction was inhibited by the induction of hypersensitive reactions in a host plant. It led to programmed cell death, which resulted in the formation of a necrotic layer to limit bacterial agents. Subscript numbers indicate day(s) after inoculation. CO indicates the control condition under which injury symptoms showed no changes throughout the experimental time series

\section{Results}

\section{Analysis of temporal progression of disease and HR}

A visual assessment of the plant-pathogen interaction for three days post inoculation revealed that the host plant differentially interacted with the $\mathrm{Xc}$ and $\mathrm{XaC}$ bacterial strains (Fig. 1). The plant-Xc pathogen interaction resulted in a progressive increase in the symptoms of the canker disease (Fig. $1 \mathrm{~A}_{1}-1 \mathrm{~A}_{3}$ ), while the pathogen $\mathrm{XaC}$ induced $\mathrm{HR}$ in the infected leaves and subsequently caused the appearance of necrotic rings around the inoculum regions (Fig. $1 \mathrm{C}_{1}-1 \mathrm{C}_{3}$ ). The injury symptoms under control conditions remained unchanged (Fig. $1 \mathrm{CO}_{1}-1 \mathrm{CO}_{3}$ ).

\section{Detection and amplification of investigated miRNAs}

According to the literature, three conserved miRNAs (miR159, miR167, and miR398), which are known to be involved in the biotic stress responses of plants, were considered in this survey. Accordingly, the expression of their mature forms in lemon leaves was investigated upon $\mathrm{Xc}$ and $\mathrm{XaC}$ infections. MiRNAs and F-Box PCR products were of the expected size, $60-65 \mathrm{bp}$ and $114 \mathrm{bp}$ in length, respectively. The investigated miRNAs were successfully detected and amplified using stem-loop RT-PCR in a non-model plant.

\section{Expression patterns of miRNAs upon Xanthomonas infection}

To investigate the temporal expression patterns of miR159, miR167, and miR398 upon inoculation with Xc and $\mathrm{XaC}$, relative quantifications of the miRNA expression levels were performed using stem-loop RT-qPCR during seven post-infection time series. Except for the very early time point (i.e., $0.5 \mathrm{hpi}$ ), nearly similar expression patterns of miR159 and miR167 were noted in response to both bacterial strains (Fig. 2). A steep change in the relative expression of both miRNAs was observed during transition from 3 to $6 \mathrm{hpi}$, where we observed a change from down-regulation to up-regulation, and then, a decrease in the expression level at $12 \mathrm{hpi}$. Another increase in the expression of both miRNAs was observed (48 hpi). The relative expressions for $\mathrm{XaC}$ were significantly greater (in absolute values) than those for Xc, except at 6 and $48 \mathrm{hpi}$. At an early time point $(0.5 \mathrm{hpi})$, miR159 was down-regulated (in contrast to miR167), with greater absolute values for $\mathrm{XaC}$ than for $\mathrm{Xc}$.

Although the relative expression patterns of miR398 were distinct from those of miR159 and miR167, the trends of miR398 expressions were similar against both bacterial strains. The level of miR398 decreased at early infection times ( 0.5 and $3 \mathrm{hpi}$ ). A sharp increase ( $6 \mathrm{hpi}$ ) in the expression levels was observed for both strains, 


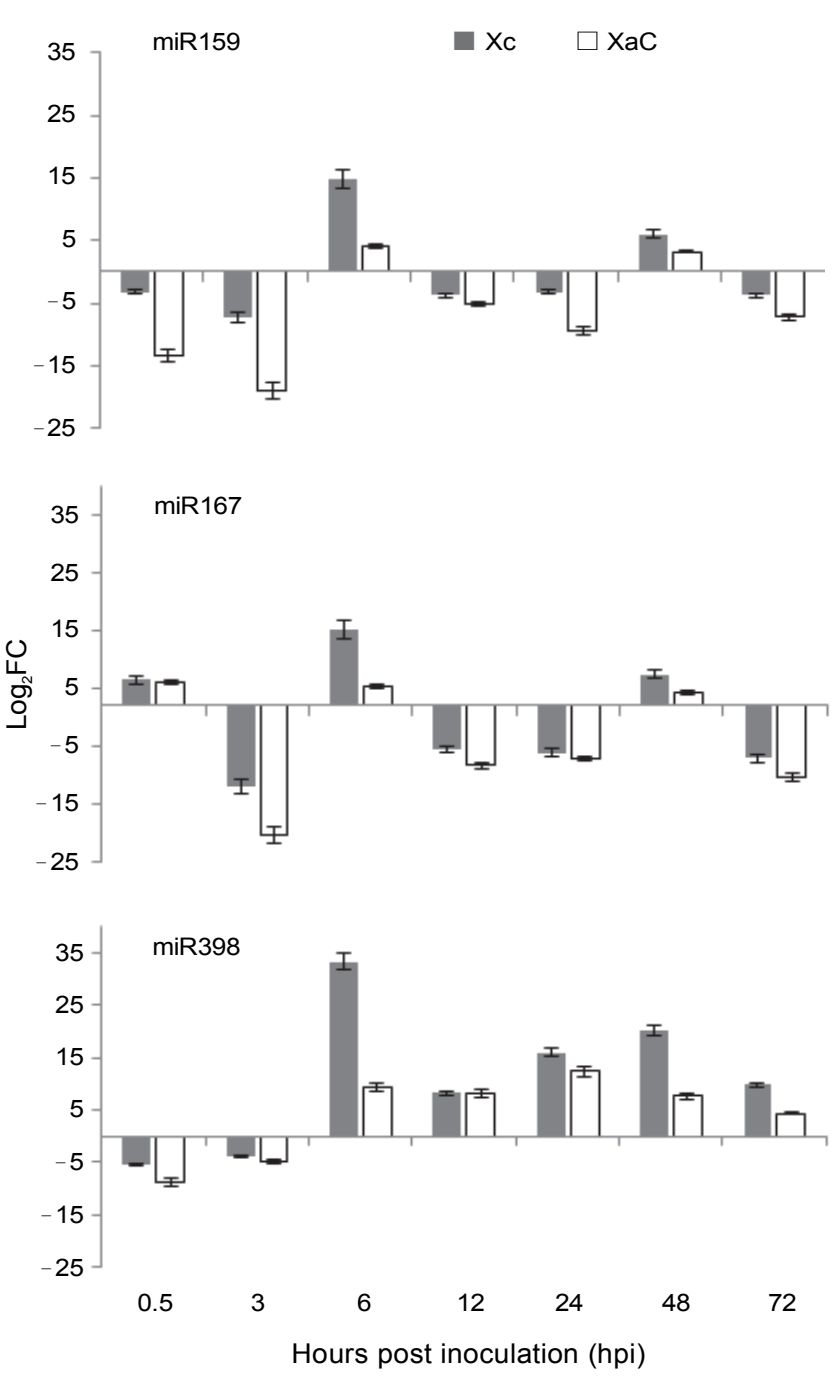

Fig. 2. Time-course expression pattern of selected miRNAs in lemon leaves upon infection with Xanthomonas Xc and XaC strains. The effect of both Xanthomonas strains on the expression levels of miR159, miR167, and miR398 was analyzed in the infected lemon leaves by using stem-loop qRT-PCR at 0.5 , $3,6,12,24,48$, and $72 \mathrm{~h}$ post infection (hpi). The vertical axis indicates $\log _{2}$ of the relative expression level or fold change $\left(\log _{2} \mathrm{FC}\right)$ where the relative expression (ratio) is the normalized expression level of miRNAs in the inoculated samples related to the control samples (non-inoculated). Data were presented as means of $\log _{2} \mathrm{FC} \pm \mathrm{SD}$

particularly upon Xc infection. Further, the increase in the miR398 level was considerably higher upon Xc inoculation than upon $\mathrm{XaC}$ infection. Up-regulation of miR398 was maintained throughout the remaining tested time points.

\section{Discussion}

Plants have an excellent capacity to recognize pathogens. Further, pathogens are capable of affecting the defense systems of plants. The pathogen Xanthomonas citrisubsp citristrain A (Xc) induces citrus canker symptoms by triggering hypertrophy and hyperplasia (Schubert et al., 2001), while Xanthomonas fuscans subsp. aurantifolii strain $\mathrm{C}(\mathrm{XaC})$ induces $\mathrm{HR}$ in certain citrus species including sweet oranges and lemon tissues (Brunings and Gabriel, 2003). An expression analysis performed by Cernadas and colleagues (2008) revealed that $\mathrm{XaC}$ induces the expression of genes, which are involved in basal defense systems, whereas Xc induces the expression of genes associated with cell division and growth (Cernadas et al., 2008). A subsequent study performed by Cernadas and Benedetti (2009) demonstrated that cell-wall remodeling genes encoding cell-wall remodeling enzymes and proteins associated with cell-wall elongation, including the beta-1,3 (B1.3G) and beta-1,4 (B1.4G) endoglucanases, acidic and basic cellulases, pectinesterase, pectinacetylesterase, xyloglucan galactosyltransferase, and expansin, are induced by Xc inoculation and auxin and gibberellin exposures. Therefore, the auxin and gibberellin hormones may play key roles in contributing to the development of citrus canker symptoms. Like other biotrophic pathogens, Xanthomonas strains can synthesize active forms of auxins to promote disease symptoms in plants (Wang et al., 2007; Chen et al., 2007).

Many studies have clearly emphasized the regulatory roles of host miRNAs in plant-pathogen interactions (Chen and Cao, 2015; Navarro et al., 2006; Zhang et al., 2011). According to our results, expression patterns of the investigated miRNAs in response to different Xanthomonas strains followed a fluctuating pattern in lemon at the analyzed time points (Fig. 2). Previously, researchers have suggested that miR159 and miR167 contribute to PTI and ETI in the Arabidopsis pseudomonas syringae interaction (Rhoades et al., 2002; Zhang et al., 2011). Thus for, the up-regulation of miR159 and miR167 at 6 hpi and again at 48 hpi might represent important time points in the cases of the $\mathrm{Xc}$ and $\mathrm{XaC}$ infections in lemon. They have also been described during the identification and characterization of differentially expressed genes for several citrus species in response to Xanthomonas spp (Cernadas et al., 2008; Khalaf et al., 2011; Shi et al., 2015; Hu et al., 2016).

The modulation of phytohormone networks in the plant-pathogen interactions has been previously reported to play a key role in plant immunity (Zhang et al., 2011). 
MiR159 and miR167, being highly conserved miRNAs involved in plant immune systems (Wu and Poethig, 2006; Reyes and Chua, 2007), have been reported to have key regulatory effects in gibberellin and auxin signaling pathways, respectively. Some $G A M Y M$-like genes (MYB33, MYB65, and MYB101), which are considered to be miR159 regulatory targets, have been reported to be among the gibberellin signaling activators (Millar and Gubler, 2005; Reyes and Chua, 2007). During the events leading to an increase in the expression level of miR159 at 6 and 48 hpi upon a Xanthomonas infection in lemon, the plant defense system may suppress gibberellin signaling, which results in a reduction of the cell growth. As reported by other researchers, miR167 through targeting ARF transcription factor family members (ARF6 and ARF8) reduces auxin signaling upon bacterial infection and therefore, diminishes the hypertrophy resulting from high levels of auxin in the plant system (Hutchison et al., 1999; Zhang et al., 2011). Interestingly, we could observe nearly the same expression patterns for miR167 and miR159 upon infection by both Xanthomonas strains. Thus, we suggest that miR159 and miR167 may play roles in the lemon defense system through the regulation of the auxin and gibberellin pathways.

MiR398 is one of the bacteria-responsive miRNAs with a proven role in regulating ROS levels as it targets SOD transcripts (CSD1 and CSD2) (Sunkar and Zhu, 2004; Bonnet et al., 2004). ROS, produced during the onset of a pathogen-induced HR, have been reported to trigger hypersensitive plant cell death (Zeier et al., 2004). SOD enzymes decrease the level of superoxide radicals by converting them into $\mathrm{H}_{2} \mathrm{O}_{2}$ and $\mathrm{O}_{2}$ (Draper, 1997). The up-regulation of miR398 as a response to the infection of both Xanthomonas strains observed in our experiments was contradictory to the findings of other researchers who reported the down-regulation of miR398 under biotic stresses (Jagadeeswaran et al., 2009, Zhang et al., 2011, Pérez-Quintero et al., 2012, Kumar et al., 2011a; Kumar et al., 2011b). Further, the time-course expression of miRNAs in the compatible and incompatible interactions of poplar-foliar rust fungus indicated that miR398 was up-regulated during post-infection periods (Chen and Cao, 2015). Note that a comparative expression analysis between the disease-inducing and the HR-inducing Xanthomonas $\mathrm{Xc}$ and $\mathrm{XaC}$ strains led to the observation of a lower relative expression of miR398 in the case of the HR-inducing isolate at all time points longer than 3 hpi. These differences in the miR398 level may suggest its possible role in the incompatible interaction that resulted in HR.

\section{Conclusions}

The experimental results indicated that stem-loop RTPCR can be used as an efficient method to detect highly conserved miRNAs in non-model plants. Moreover, the expression analysis clearly showed similar patterns for both miR159 and miR167 during infections with both bacterial strains. The expression of miR398 was differentially regulated during post-infection times. Further experiments are required to understand the citrusXanthomonas interactions. A global mRNA expression analysis at the tested time points is recommended to further confirm the observations made with respect to miRNAs.

\section{References}

Alonso-Peral M.M., Li J., Li Y., et al. (2010) The microRNA159regulated GAMYB-like genes inhibit growth and promote programmed cell death in Arabidopsis. Plant Physiol. 154: 757-771.

Barciszewska-Pacak M., Milanowska K., Knop K., Bielewicz D., Nuc P., Plewka P., Pacak A.M., Vazquez F., Karlowski W., Jarmolowski A., Szweykowska-Kulinska Z. (2015) Arabidopsis microRNA expression regulation in a wide range of abiotic stress responses. Front. Plant Sci. 6: 410.

Bartel D.P. (2004) MicroRNAs: genomics, biogenesis, mechanism, and function. Cell 116: 281-297.

Benes V., Castoldi M. (2010) Expression profiling of micro$R N A$ using real-time quantitative PCR, how to use it and what is available. Methods 50: 244-249.

Bonnet E., Wuyts J., Rouzé P., Van de Peer Y. (2004) Detection of 91 potential conserved plant microRNAs in Arabidopsis thaliana and Oryza sativa identifies important target genes. Proc. Natl Acad. Sci. USA 101: 11511-11516.

Brunings A.M., Gabriel D.W. (2003) Xanthomonas citri: breaking the surface. Mol. Plant Pathol. 4: 141-157.

Carrington J.C., Ambros V. (2003) Role of microRNAs in plant and animal development. Science 301: 336-338.

Cernadas R.A., Camillo L.R., Benedetti C.E. (2008) Transcriptional analysis of the sweet orange interaction with the citrus canker pathogens Xanthomonas axonopodis $p v$. citri and Xanthomonas axonopodis pv. aurantifolii. Mol. Plant Pathol. 9: 609-631.

Cernadas R.A., Benedetti C.E. (2009) Role of auxin and gibberellin in citrus canker development and in the transcriptional control of cell-wall remodeling genes modulated by Xanthomonas axonopodis pv. citri. Plant Sci. 177: 190-195.

Chen C., Ridzon D.A., Broomer A.J., et al. (2005) Real-time quantification of microRNAs by stem-loop RT-PCR. Nucl. Acids Res. 33: e179. 
Chen Z., Agnew J.L., Cohen J.D., et al. (2007) Pseudomonas syringae type III effector AvrRpt2 alters Arabidopsis thaliana auxin physiology. Proc. Natl Acad. Sci. USA 104: 20131-20136.

Chen M., Cao Z. (2015) Genome-wide expression profiling of microRNAs in poplar upon infection with the foliar rust fungus Melampsora larici-populina. BMC Genom. 16: 1471-2164.

Denancé N., Sánchez-Vallet A., Goffner D., Molina A. (2013) Disease resistance or growth: the role of plant hormones in balancing immune responses and fitness costs. Front. Plant. Sci 4: 155.

Draper J. (1997) Salicylate, superoxide synthesis and cell suicide in plant defence. Trends Plant Sci. 2: 162-165.

Economos C., Clay W.D. (1999) Nutritional and health benefits of citrus fruits. Food Nutr. Agric. 24: 11-18.

Glazińska P., Wojciechowski W., Wilmowicz E., et al. (2014) The involvement of InMIR167 in the regulation of expression of its target gene InARF8, and their participation in the vegetative and generative development of Ipomoea nil plants. J. Plant Physiol. 171: 225-234.

Heidrich K., Blanvillain-Baufumé S., Parker J.E. (2012) Molecular and spatial constraints on NB-LRR receptor signaling. Curr. Opin. Plant Biol. 15: 385-391.

Hu Y., Duan S., Zhang Y., et al. (2016) Temporal transcription profiling of sweet orange in response to PthA4-mediated Xanthomonas citri subsp. citri infection. Phytopathology 106: 442-451.

Hutchison K.W., Singer P.B., McInnis S., et al. (1999) Expansins are conserved in conifers and expressed in hypocotyls in response to exogenous auxin. Plant Physiol. 120: 827-832.

Jagadeeswaran G., Saini A., Sunkar R. (2009) Biotic and abiotic stress down-regulate miR398 expression in Arabi dopsis. Planta 229: 1009-1014.

Jones J.D., Dangl J.L. (2006) The plant immune system. Nature 444: 323-329.

Khalaf A.A., Gmitter F.G., Conesa A., et al. (2011) Fortunella margarita transcriptional reprogramming triggered by Xanthomonas citri subsp. citri. BMC Plant Biol. 11: 14712229 .

Khraiwesh B., Zhu J.K., Zhu J. (2012) Role of miRNAs and siRNAs in biotic and abiotic stress responses of plants. Biochim. Biophys. Acta 1819: 137-148.

Kramer M.F. (2011) STEM-LOOP RT-qPCR for miRNAS. Current protocols in molecular biology. Ed. Ausubel F.M. et al. Unit15.10.

Kumar N., Ebel R.C., Roberts P.D. (2011a) H2O2 metabolism during sweet orange (Citrus sinensis L. Osb.) 'Hamlin' Xanthomonas axonopodis pv. citri interaction. Sci. Hort. 128: 465-472.

Kumar N., Ebel R.C., Roberts P.D. (2011b) Superoxide dismutase activity in kumquat leaves infected with Xanthomonas axonopodis pv. citri. J. Hortic. Sci. Biotechnol. 86: 62-68.

Li Y., Zhang Q., Zhang J., et al. (2010) Identification of microRNAs involved in pathogen-associated molecular pattern-triggered plant innate immunity. Plant Physiol. 152: 2222-2231.

Lin H.C., Hsu S.T., Tzeng K.C. (2009) Histopathology and bacterial populations of atypical symptoms-inducing Xanthomonas axonopodis pv. citri strains in leaves of grapefruit and mexican lime. J. Plant Path. 18: 125-134.

Livak K.J., Schmittgen T.D. (2001) Analysis of relative gene expression data using real-time quantitative PCR and the $2^{-\triangle C T}$ method. Methods 25: 402-408.

Mafra V., Kubo K.S., Alves-Ferreira M., et al. (2012) Reference genes for accurate transcript normalization in citrus genotypes under different experimental conditions. Plos One 7(2): e31263.

Millar A.A., Gubler F. (2005) The Arabidopsis GAMYB-like genes, MYB33 and MYB65, are microRNA-regulated genes that redundantly facilitate anther development. Plant Cell 17: 705-721.

Morel J.B., Dangl J.L. (1997) The hypersensitive response and the induction of cell death in plants. Cell Death Diffe 4: 671-683.

Navarro L., Dunoyer P., Jay F., et al. (2006) A plant miRNA contributes to antibacterial resistance by repressing auxin signaling. Science 312: 436-439.

Nicaise V., Roux M., Zipfel C. (2009) Recent advances in PAMP-triggered immunity against bacteria: pattern recognition receptors watch over and raise the alarm. Plant Physiol. 150: 1638-1647.

Pérez-Quintero A.L., Quintero A., Urrego O., et al. (2012) Bioinformatic identification of cassava miRNAs differentially expressed in response to infection by Xanthomonas axonopodis pv. manihotis. BMC Plant Biol. 12: 29.

Reyes J.L., Chua N.H. (2007) ABA induction of miR159 controls transcript levels of two MYB factors during Arabidopsis seed germination. Plant J. 49: 592-606.

Rhoades M.W., Reinhart B.J., Lim L.P., et al. (2002) Prediction of plant microRNA targets. Cell 110: 513-520.

Rouseff R.L., Nagy S. (1994) Health and nutritional benefits of citrus fruit components. Food Tech 48: 125-132.

Ruijter J.M., Ramakers C., Hoogaars W.M.H., et al. (2009) Amplification efficiency: linking baseline and bias in the analysis of quantitative PCR data. Nucl. Acids Res. 37: e45.

Schubert T.S., Rizvi S.A., Sun X., et al. (2009) Meeting the challenge of eradicating citrus canker in Florida-Again. Plant Dis. 85: 340-356.

Shi Q., Febres V.J., Jones J.B., Moore G.A. (2015) Responsiveness of different citrus genotypes to the Xanthomonas citri ssp. citri-derived pathogen-associated molecular pattern (PAMP) flg22 correlates with resistance to citrus canker. Mol. Plant Path. 16: 507-520.

Sunkar R., Zhu J.K. (2004) Novel and stress-regulated micro$R N A s$ and other small RNAs from Arabidopsis. Plant Cell 16: 2001-2019.

Sunkar R., Kapoor A., Zhu J.K. (2006) Posttranscriptional induction of two $\mathrm{Cu} / \mathrm{Zn}$ superoxide dismutase genes in Arabidopsis is mediated by down-regulation of miR398 and 
important for oxidative stress tolerance. Plant Cell 18: 2051-2065.

USDA (2013) http://indexmundi.com/agriculture/?commodity $=$ lemons\&graph $=$ production.

Varkonyi-Gasic E., Wu R., Wood M., et al. (2007) Protocol: a highly sensitive RT-PCR method for detection and quantification of microRNAs. Plant Meth. 3: 12.

Viloria Z., Drouillard D.L., Graham J.H., Grosser J.W. (2004) Screening triploid hybrids of 'Lakeland' limequat for resistance to citrus canker. Plant Dis. 88: 1056-1060.

Wang D., Pajerowska-Mukhtar K., Culler A.H., Dong X. (2007) Salicylic acid inhibits pathogen growth in plants through repression of the auxin signaling pathway. Curr. Biol. 17: 1784-1790.
Wu G., Poethig R.S. (2006) Temporal regulation of shoot development in Arabidopsis thaliana by miR156 and its target SPL3. Development 133: 3539-3547.

Zeier J., Delledonne M., Mishina T., et al. (2004) Genetic elucidation of nitric oxide signaling in incompatible plantpathogen interactions. Plant Physiol. 136: 2875-2886.

Zhang W., Gao S., Zhou X., et al. (2011) Bacteria-responsive microRNAs regulate plant innate immunity by modulating plant hormone networks. Plant Mol. Biol. 75: 93-105. 